\title{
THE DEVELOPMENT OF NEW ORGANIZATION FORMS OF WHOLESALE TRADE ENTERPRISES IN RUSSIA
}

\author{
Удк 338
}

Andrey N. Vashchekin,

$\mathrm{PhD}$ in Economics, Associate Professor, Competitor for Doctoral degree

Professor of the Moscow State University of Economics. Statistics and Informatics Tel.: (495) 331-09-70

E-mail:Vaschekin@mail.ru

The new conditions of wholesale business in Russia, formed by the economic reforms, led the formation and development of qualitatively different trading activity forms, new organization types, which involves reconsideration of traditional wholesale enterprises modeling concepts. In the near future market will be dominated with wholesale and retail associations. Competing with each other, they will gradually grow by the addition of small commercial enterprises. There is also the emergence of not previously encountered universal dual-use forms of trade organization resulting from the penetration of network technologies in management.

Keywords: wholesale structures, trade forms integration, formalization, modeling.

Андрей Николаевич Ващекин,

к.э.Н., доцент, соискатель докторской степени

Московский университет экономики, статистики и информатики

Тел.: (495) 331-09-70

Эл. почта: Vaschekin@mail.ru

\section{РАЗВИТИЕ НОВЫХ}

ОРГАНИЗАЦИОННЫХ ФОРМ

ОПТОВЫХ ТОРГОВЫХ

ПРЕДПРИЯТИЙ В РОССИИ

Новые условия оптовой торговли в России, сформированные экономическими реформами, привели к формированию и развитию качественно отличающихся форм торговой деятельности, новых типов организаций, которые включают пересмотр модулирующих концепций традиционных оптовых предприятий. В ближайшем будущем на рынке будут доминировать с оптовые и розничные ассоциации. Конкурируя друг с другом, они будут постепенно расти, присоединяя небольшие коммерческие предприятия. Также появятся универсальные дуальные формы торговых организаций, с которыми ранее не сталкивались. Это происходит из-за проникновения сетевых технологий в управление.

Ключевые слова: оптовые структуры, интеграция фрорм торговли, формализация, моделирование.

\section{Introduction}

The new conditions of wholesale business in Russia, formed by the economic reforms, led the formation and development of qualitatively different trading activity forms, new organization types, which involves reconsideration of traditional wholesale enterprises modeling concepts.

Lasting period of chaotic development of the trading industry, which began in 1992 with the elimination of central control of trade patterns, so-called «torgs», as well as other industry and local associations, continued privatization of old traders accompanied by the creation of a huge number of new commercial properties as a rule small in size. [1]

The only criterion for the success of new business owners was considered income, while not focusing on the effect - the amount of profit, but on the efficiency - the level of profit as a percentage of turnover.

Rejection from the distribution, supply and managerial functions of trade has led to a complete break of previous branch and regional schemes in logistic and support. Only in the second half of the 90s last century, the need to create a qualitatively new system of trade governance at both the macro and micro levels made itself felt.

Gradually it began to emerge associations, corporations, trade groups without any territorial boundaries in order to improve their member companies opportunities to compete on price, level of service, qualifications of personnel, the provision of the necessary volumes of goods and services. The most important qualitative feature of these structures was the development of the overall marketing strategy, defining the development strategy, the introduction of new trade methods and technology.

Both retail and wholesale trade enterprises began looking for ways to recreate the interaction with each other, but not on the basis of the previous trading system, and on a qualitatively new basis. Consolidation of trading patterns often occurred «from the top», by absorbing or attracting a large enterprise to smallscale cooperation partners in order to expand its network, but just as often, and «from below» through cooperation, that is, combining multiple equal partners in order to create a common coordinating structure.

An open competition with foreign trade empires which had come on the domestic market contributed greatly to this cooperation. This combining continued in the first decade of the XXI century. [2]

A network of supermarkets, gas stations, bakeries sprung up. A large number of the network of shops selling goods of light and textile industry and members of the joint-stock companies in these industries spread. Meat processing plants, dairies, have set up their network of small business enterprises.

There appeared large associations of traders, specializing in the sale of household goods and electronics (mainly imported), computers (often produced in Russia from imported parts), dealer Car trade networks of certain manufacturers. As a rule, the association of trade enterprises is not within the administrative unit, and on the profile of specialization. The corporation, covering several industries, including the production and sale of goods with their banks arose.

\section{Russian wholesale trade enterprises in modern conditions}

An important motive that generates the desire to integrate commercial structures is the lack of working capital, particularly acute in the background of prevailing in Russia inefficient lending system [3].

The formation of such associations does not necessarily mean a change of ownership in the owners hands of the control (center) company. The overriding principle of voluntariness and mutual benefit remains, often with the use of leases, considered here as a term management contracts. 
However, in the case of a more rigid vertical chain, organized, for example, to operate under the parent company brand name, the union may be able to operate only with the full inclusion of its members in business activity of the parent structure. There is another form of integration - the creation of associations of associative type, providing coordination and centralization of performing only the most important functions of their commercial policy.

An alternative to the above two types of corporations are trade associations type of the contract, designed to coordinate the functions of the wholesale and retail trade on the principles of general business strategy while maintaining full legal and financial independence of each member of the association. This retail structures included in the circuit, typically have a single brand name.

A contributes to a large extent to the development of bilateral trade integration process in the ever-increasing number of wholesale businesses. From 2003 to 2012 it has doubled and now exceeds 800,000 . In this case, the total turnover of the wholesale enterprises from 2000 to 2012 increased by 10 times, and in comparable prices increased by one and half.

Among the trade enterprises the wholesalers were subjected to the greatest transformation of the reforms. [4] Wholesale enterprises that existed in Soviet times often could not keep up with the demands of a dynamic market because of their large size and more complex internal structure of management.

Undoubtedly, there are numerous serious difficulties in the formation of trade patterns mixed network: an inconvenient tax regime, bureaucratic difficulties in land acquisition and design documentation for the facilities, the trained personnel lack, lack of investment funds for the construction of distribution centers and the introduction of automated communication and control systems.

Depending on who is creating a new structure - a group of retailers, which extends the scope of activities, wholesaler seeking to provide a stable sales of their goods, or an investor who creates a new efficient business - these problems can have a different effect on the final result.

Among the new wholesale structures that have emerged in the course of reform, it should be mentioned commodity exchanges. A specific feature of the transition period was the formation of an astronomical number of these enterprises. Already during 1991, that is, even before a liberalization of prices in Russia there were more than a hundred trade, commodities, commodity and stock exchanges. Note that for such a large number of these exchanges they provided a negligible market share of supply of goods.

The rapid growth in the number of exchanges continued in 1992, and then, as a result of the federal law governing the exchange activity adoption, the stock exchanges were closed because they do not follow a particular concept in the law of the exchange. By the end of the 90s the vast majority of exchanges either went bankrupt or refused to conduct commercial transactions by going to transactions in securities. The trend continued in the following years: the number of commodity exchanges and stock exchanges commodity divisions from 2000 to 2012 decreased threefold.

Partly of exchange-traded structure compensate reducing of the number by work activity. Number of trades carried out by them during the same period increased by $20 \%$, while the number of transactions has increased by almost 3 -fold, respectively, and the turnover increased. It should be noted, however, that this kind of renaissance exchange activity takes place in a very narrow sector: the auction is currently dominated by sales of fuel, oil and oil products $(90.1 \%$ of stock market turnover). Noticeable, but not comparable proportions in stock trading only agro products have $(7.1 \%)$, and even chemical products $(1.8 \%)$ [1].

Meanwhile, such change in the profile of commodity exchanges can not have a positive impact on the wholesale market further development, as the need for their existence as a distinct element of the wholesale market structure is preserved. Ideally mercantile exchange is designed to serve as a forward-looking indicator of price movements and is an important tool for the redistribution of financial risk between the different market structures, to be a kind of consumer market pulse. Both physical consumer goods in the form of standard and forward contracts and futures contracts for the goods supply can be objects of trade on a commodity exchange.

Since the mid 90's increasing importance gained another kind of commercial enterprises - the wholesale markets. In fact, moving from stationary trade, equipped and adapted for it premises on the market - in the pavilions, tents, stalls, kiosks, trays, the propagation of primitive forms of trading service means the abandonment of the past. And yet, despite all the negative factors of this form of trading one positive was decisive: the minimum cost of renting space and avoiding the purchase of additional equipment allows merchants to sell products at prices $15-20 \%$ lower than do stationary companies do.

Over the last fifteen years in the major cities wholesale and retail markets provided for more than half of the population with food, tobacco, household chemicals, etc. In general, they are largely satisfied the needs of the population in the goods of daily demand. However, this form of trade is not perspective as it generates a huge number of violations of trade rules, difficult to account for and control, and, in essence, is a form of tax havens, even though tax revenues from markets provided, for example, the firm $10 \%$ of the city budget in Moscow, in this period.

But the future of markets is already defined. They are doomed to transformation or liquidation. Qualitatively, they are converted to shopping centers, capable of large-volume, fast turnover and minimize distribution costs to keep prices low. The number of trading places in the markets from 2005 to 2012 was cut in half [1].

Finally, it is necessary to mention an entirely new form of trade association the pool of non-competing retailers, which includes companies specializing in wholesale and retail trade in various market segments. Creating a pool is important to observe two conditions: mutual complement and total completeness. This means on the one hand, none of the participants in the pool does 
not have to qualify for the conduct of business activities in the area, which is the basis for the other party. On the other hand, the amount of these members should preferably cover the entire spectrum of market segments.

The first such association appeared in Russia at the beginning of this century as a result of the successful interaction of several leading trade corporations and is known as the first six digits of the telephone number, which brings together participants (last digit corresponds to a particular member of the pool). The main objective of the company (let's call it for short «Pool») an increase in the market share of all participants by combining customer flows.

At the initial stage the cooperation was limited to cross-marketing programs, which were attended by a maximum of two or three networks. The next venture that united the participants of the project was the creation of a common information field. According to estimates of the participants, the increase in demand for retail chains in the Pool, as a result of the introduction of the information field is about $30 \%$. As a part of the Pool in 2003 a single discount card was introduced and being issued to the purchaser of one of the permanent Pool members, urged him to make purchases from other members.

The reason for the entry of new participants in the Pool was the fact that these companies have been most successful in their market segment. Each of the companies remains a leader in its field, using a network organizing principle of the sale of goods and services, focused on offer only quality products and service, takes a proactive marketing position and does not have a competitive overlaps with other Pool members, which corresponds to the same principles.

And although in 2007 Pool ceased to exist as a single entity, the emergence of such a powerful combination of wholesale and retail networks, possibly the reflected the high level of integration of sale in the greatest degree, made to date.

It is noted the appearance of not previously encountered universal dual-use forms of trade organization resulting from the penetration of network technologies in management. In these structures, there is no explicit link wholesale and no warehouse concentrated in one geographical point. These functions take the retail units are actively cooperating «horizontally».

\section{The development of trade forms integration in Russia}

In view of the above-mentioned trends it is possible to predict the direction of further trade forms development in the coming years. First of all, the market will be dominated with wholesale and retail associations. Competing with each other, they will gradually grow by the addition of small commercial enterprises. Each of these organizations will seek to dominate a sector, but nonetheless together they will form a dynamic and coherent enough trading system.

In large cities, such a system can have multiple levels. Currently in Moscow, which of course is an direction of trade indicator in general, three such levels have been already formed: local, urban and inter-regional. These levels are distinguished by population service radius, time availability, range and variety of services.

Subsystem of local shop level (with service radius of up to 500 meters, that is $7-10$ minutes walking distance) provides a guaranteed level of social services by everyday objects and partially periodic demand, approximate to housing.

The maintenance of urban values subsystem (with a radius of 15-60 minutes of service of transport and walking) provides periodic need for the goods and the unique demand, major shopping objects are placed in the public major urban centers, on the basic transportation and communication nodes of the city.

The inter-regional significance subsystem (service radius has no normalization) is designed for occasional specialized services of direct and day-time Moscow population (the inhabitants of the city of Moscow, the Moscow region and surrounding areas), with the possible placement of large commercial facilities in wholesale and retail trade on the territory of Moscow and Moscow region.

Typical for the end of the XX century feature of Russia's trade - a lack of retail space - provided the conditions for successful investment in the construction of new ones. Many foreign companies, creating new trading networks, or (more rarely) acquiring existing for subsequent upgrades, came in Russia.

This is accompanied by the formation of three types of major trade institutions: large commercial facilities, shopping complexes and shopping areas, different place of accommodation in the city, quantitative and qualitative indicators of service.

Shopping facilities are located along the city's main thoroughfares, near metro stations and in the shopping malls, and have a capacity of 10 thousand square meters of floor area.

Commercial complexes are located in the center of the city, as in certain regions, and as a part of multi-functional centers, marked with a capacity of up to 100 thousand square meters of floor area.

Shopping areas are located at the urban roads intersections (in Moscow - the circumferential and radial), including at the entrances to the city, in the direction of the satellite cities, airports, railway terminals, and have a capacity of up to 200-400 thousand square meters of floor area. The structure of the shopping area includes retail and wholesale trade sets (large multipurpose shopping centers, wholesale food markets, etc.), as well as logistics and transport purposes (distribution warehouse centers, garage systems for passenger cars and heavy vehicles, parking lots, objects of transport service etc.).

An important point is the dispersal of trading activity on the city territory with priority placement of large shopping centers in the middle and peripheral zones. In any major city in the development of commercial network should lead to a leveling of the existing trade imbalances in the trade network distribution in the city, priority placement of new construction in areas with the highest shortage of retail space. It should provide an increase in capacity of enterprises and retail outlets, including the construction of large commercial facilities.

In order to complete this task successfully it is necessary to take a 
reservation of the urban areas liable to further complex reorganization with the arrangement purpose of the multifunctional community centers (and they include large shopping centers).

The development of such a system must raise without fail the level of availability of socially important objects of trade.

Of course, the development of such systems is not possible without a corresponding structure improvement of the wholesale chain. It seems that the optimal share of wholesale trade fairs, auctions and commodity exchanges in the trade volume should be about $25 \%$. The role of wholesalers - middlemen will be resized.

Companies - distributors will play an important role in the continued dominance of imported goods on the Russian consumer market. These firms, using its unique position in the promotion of certain products are capable of providing a full range of services: warehousing services (renting space, terminals), transport services (transported to the shops), packaging products and order placement, processing, packaging, the bar code application, supply equipment, goods booking, assistance in dealing with the railways, etc.

Subject to the growth of the Russian economy the value of wholesale trade enterprises established by domestic producers for sale of their products will grow. The largest of these producers will be able to create an entire marketing system, including several sales groups (wholesale business).

Note that most of the foreign manufacturers operating in the Russian market has no its own distribution network, and works through intermediaries. Maybe in a more advanced and progressive sales system than theirs, and will be awarded one of the factors will be that will lead to the prevalence of domestic over foreign products in the domestic market.

Seems quite possible the development of new Russian retail chains, designed for small wholesalers who can replace individual wholesale markets. Consumers of retail and wholesale supermarkets will be able to come to them to buy small quantities of goods and provide with them the needs of retailers. Such systems are common in developed countries.

And finally, it can expected in the near future the development of the most deep and broad integration forms - union of trade structures with manufacturers and financial institutions and the creation of a single economic systems - trade and will financialindustrial groups, which will be a winwin for all participants and raises the process of structural trade adjustment to a new level.

It should be born in mind that the creation of trade and financial-industrial groups can have a real impact on the trade restructuring in order to eliminate the development imbalance of its individual units, as well as abruptly enhance the structures that are included in the internal economic group potential, and on this basis to create special selffinancing mechanisms, increase their investment activity in the consumer market. [2]

This integration opens up prospects for the development of new wholesale technologies and warehouse commercial operations and the provision of freight forwarding services for cargo with minimal cost in a short time, the rational use of the rolling stock.

The natural question is: how useful are all occurring in wholesale trade enterprises transform of actions for trade itself? Indirectly, though implicit factor for the effectiveness of trade as a result of its restructuring over the past ten years, is a constant (and even accelerating over time), number of warehouses reducing. Perhaps, given the sharp decline of trade in the 90 s compared with the $80 \mathrm{~s}$, a number of storage areas proved to be unnecessary.

It is impossible, however, to deny that in terms of stabilization of the economy in the first decade of the XXI century, when the sales of wholesale organizations began to grow annually by tens of percents, the number and area of wholesale stores in the country do not grow. This is, perhaps, have an undeniable effectiveness indicator of recent years new forms of commercial enterprises, largely reflecting the increasing speed with which the product finds its consumer.

The only criterion for the effective operation of any commercial enterprise, including wholesale, it is a financial success. On this basis it can be assumed that the wholesale company should be considered to serve on the market only in terms of profitability, preferring the more lucrative and abandoning less profitable.

But here's the paradox: as soon as the company does not wish to or can not carry out at least some of its functions, there and then another company will appear that would be able to offer services in their implementation. The customer for this "discriminating» wholesaler is partially lost. And then, suddenly, competitor company gradually will take all other functions of wholesale businesses to it hands and will consider them as its native.

Therefore, we take as a postulate the following statement: in order to live successfully in the wholesale market, the company must carefully analyze its functions performed in this market, while constantly seeking to supplement the list of services provided with it, and in any case not allowing reduction of the list, varying amounts of their services based on customer requests.

In modern conditions, the wholesale trade company success in the market is determined not so much by a rational business organization, reducing circulation costs from internal reserves, increased productivity and efficient use of all resources, but rather by how well wholesale trade enterprise adapts to its external environment - the economic, socio-political, etc.

It should be noted that in general the basis of the totality of economic entities in the market economy are the so-called «open systems», the main prerequisites for the success of which are found not inside them, but out of them [6]. The wholesale enterprises organization by through the establishment on the basis of each of them of an open economic system allows to formulate the strategic development general directions of these enterprises in specific circumstances.

\section{Литература}

1. Россия в цифрах - 2013. http:// www.gks.ru/bgd/regl/b13_11/Main. htm

2. Vashchekin A.N. Features of Business Wholesale Trade Companies in Russia // International Conference 
«Global Science and Innovation» LLC «Strategic Studies Institute», Chikago, 2013. - P. 221-224.

3. Vashchekin A.N. Role of the wholesale enterprises in regulation of the inter-branch relations under insufficient current assets // Economics and Politics of Russia and the near abroad, 2003, - T.9. - P. 49-52.

4. Vashchekin A.N. The functional basis and features of business wholesale trade companies in Russia // Экономика, статистика и информатика. Вестник УМО МЭСИ, - 2014, №2. - C. 42-45.

5. Vashchekin A.N. The optimal strategy of wholesale trade enterprise development in Russia // 5th Conference «Applied Sciences and technologies in the United States and Europe: common challenges and scientific findings», New York, 2014, - P. 181-182.

6. Lovtsov D.A. Models for measuring the information resource of a computerized control system // Automation and Remote Control, - 1996. T. 57, № 9, Part 1. - P. 1221-1232.

\section{References}

1. Rossiya v cifrah - 2013. http:// www.gks.ru/bgd/regl/b13_11/Main.htm

2. Vashchekin A.N. Features of Business Wholesale Trade Companies in Russia // International Conference «Global Science and Innovation» LLC «Strategic Studies Institute», Chikago, 2013. - P. 221-224.

3. Vashchekin A.N. Role of the wholesale enterprises in regulation of the inter-branch relations under insuf- ficient current assets // Economics and Politics of Russia and the near abroad, 2003, - T.9. - P. 49-52.

4. Vashchekin A.N. The functional basis and features of business wholesale trade companies in Russia // Ekonomika, statistika i informatika. Vestneyk UMO MESI, - 2014, №2. - S. 42-45.

5. Vashchekin A.N. The optimal strategy of wholesale trade enterprise development in Russia // 5th Conference «Applied Sciences and technologies in the United States and Europe: common challenges and scientific findings», New York, 2014, - P. 181-182.

6. Lovtsov D.A. Models for measuring the information resource of a computerized control system // Automation and Remote Control, - 1996. T. 57, № 9, Part 1. - P. 1221-1232. 